\title{
Prebiotic Activity and Bioactive Compounds of the Enzymatically Depolymerized Thailand-Grown Mangosteen Aril
}

\author{
Pranee Anprung (Corresponding author) \\ Department of Food Technology, Faculty of Science \\ Chulalongkorn University, Bangkok 10330, Thailand \\ Tel: 66-022-185-530 E-mail: pranee.a@chula.ac.th \\ Sasina Sangthawan \\ Program in Biotechnology, Faculty of Science \\ Chulalongkorn University, Bangkok 10330, Thailand \\ Tel: 66-023-803-032 E-mail: froggy11346@hotmail.com
}

$\begin{array}{lc}\text { Received: November 14, } 2011 & \text { Accepted: November 28, } 2011 \quad \text { Published: February 1, } 2012 \\ \text { doi:10.5539/jfr.v1n1p268 } & \text { URL: http://dx.doi.org/10.5539/jfr.v1n1p268 }\end{array}$

\begin{abstract}
The aim of this research was to investigate the effect of pectinase on prebiotic activity and bioactive compounds of enzymatically depolymerized Thailand-grown mangosteen aril. It was found that after varying enzyme concentration in $0-3.0 \%(\mathrm{v} / \mathrm{w})$, mangosteen aril treated with enzyme concentration of $2.5 \%(\mathrm{v} / \mathrm{w})$ and hydrolyzed for $0,1,2,4$ and $6 \mathrm{~h}$ can be hydrolyzed at 5 different levels of reducing sugar. They were 18, 25, 31, 40 and 45 $\mathrm{mg}$ glucose/g fresh weight. Hydrolysis of mangosteen aril at $6 \mathrm{~h}$ resulted in the highest release of bioactive compounds with the antioxidant activity value measured by DPPH assay $\left(\mathrm{EC}_{50}\right)$ of $3.05 \mu \mathrm{g} \mathrm{dw} / \mu \mathrm{g} \mathrm{DPPH}$ and FRAP value of $45.53 \mu \mathrm{M} \mathrm{TE} / \mathrm{g} \mathrm{dw}$. Total phenolic content was $16.00 \mathrm{mg} \mathrm{GAE} / \mathrm{g} \mathrm{dw}$, total flavonoid content was $3.08 \mathrm{mg} \mathrm{CE} / \mathrm{g} \mathrm{dw}$, and soluble dietary fiber was increased to $16.56 \mathrm{~g} / 100 \mathrm{~g} \mathrm{dw}$. Moreover, enzymatically depolymerized mangosteen can increase prebiotic activity score of L. acidophilus and B. lactis to 0.21 and 0.17 , respectively.
\end{abstract}

Keywords: Mangosteen, Pectinase, Antioxidant, Phenolic, Fiber, Prebiotic

\section{Introduction}

Garcinia mangostana Linn., mangosteen is one of the most praised tropical fruits and belongs to the family Clusiaceae (syn. Guttiferae). The major producing countries are found in Southeast Asia, namely Malaysia, Philippines, Indonesia and Thailand. About $85 \%$ of the total production of four countries is in Thailand. Mangosteen cultivation in Thailand is limited to the South and the East due to climatic condition. Commercial orchards have been well established in Surat Thani province in the South, and Chanthaburi and Rayong provinces in the East (Morton, 1987; Osman, 2006). The edible aril is white, soft, juicy, sweet and slightly sour taste (Zadernowski, 2009; Yu et al., 2007; Palapol et al., 2009). It can be stored only for short time period, mainly consumed fresh and can also be canned, frozen or processed into juice, jam, preserve, syrup and candy (Morton, 1987; Osman, 2006). Moreover, the mangosteen aril contains many bioactive compounds such as phenolic, flavonoid and other antioxidants which are our first line of defense against free radical damage, and are critical for maintaining optimum health and well-being (Percival, 1996). Total dietary fiber found in this fruit can be divided into insoluble and soluble dietary fiber (pectin). Furthermore, it also contains many vitamins and minerals including vitamin A, vitamin $\mathrm{C}$, thiamine, riboflavin, niacin, calcium, phosphorous, and iron (Osman, 2006). Plant cell wall consists of cellulose, hemicelluloses and pectin, which is barrier for the release of the intracellular substances. In addition, there are many phenolic hydroxyl groups existing in flavonoids which can combine with cellulose, hemicelluloses and pectin as complexes due to hydrogen bonding interactions (Fu et al., 2008). 
These bioactive compounds can be extracted by many methods. One example is the extraction with solvents such as ethanol, methanol, hexane, and acetone. Nevertheless, this method dissociates the carotenoid pigments from the proteins and causes water insolubility and ease of oxidation (Cinar, 2005.a). While releasing of the carotenoid by enzyme extraction from orange peel, sweet potato and carrot, these pigments remain in their natural state binding with proteins. This bond structure prevents pigment oxidation and also affects colour stability (Cinar, 2005.b). There are several studies on enzymatic extraction to increase the extractability of bioactive compounds. These were enhancement of anthocyanins and other phenolics in black currant juice (Landbo and Meyer, 2004), enrichment of antioxidant phenols from pomace for the production of puree-enriched cloudy apple juices (Oszmiański et al., 2011), increasing of polyphenol and polysaccharide composition of red wines (Ducasse et al., 2010), improvement of the quality of black tea extracts (Chandini et al., 2011), increasing of the phenolic content of virgin olive oil (Najafian et al., 2009), enzyme-assisted extraction of antioxidants from vegetal matrixes (Pinelo and Meyer, 2008), and increasing of lycopene from tomato tissues (Choudhari and Ananthanarayan, 2007). Additionally, there were also increasing of carotenoid, antioxidant activity, soluble dietary fiber and volatile substances from bael fruit hydrolysate, and flesh and placenta of Sunlady cantaloupe (Charoensiddhi and Anprung, 2010; Wuttisit and Anprung, 2011). These studies represent the benefits of enzyme hydrolysis.

There are many enzymes that increase the extractability of bioactive compounds such as cellulase, beta-glucosidase, pectinase (Fu et al., 2008; Cinar, 2005.b). Pectinase enzyme was used in this study because it helps to release bioactive compounds from plant cell wall. The Pectinex ${ }^{\mathbb{E}}$ Ultra SP-L, pectinase enzyme, a liquid commercial enzymatic preparation from Aspergillus aculeatus, is currently using as a pectinolytic and cellulolytic preparation in fruit juice processing (Ghazi et al., 2007). So, this research was to investigate the effect of pectinase on prebiotic activity and bioactive compounds of enzymatically depolymerized Thailand-grown mangosteen aril, and expected that the enzymatically depolymerized mangosteen aril would be effectively used as sources of antioxidant, dietary fiber, and prebiotic. Moreover, this study is an alternative processing way to add the value of the mangosteen which is one of the traditional economic fruits (Thailand had the highest mangosteen production, so the mangosteen is vital to the economy of the country).

\section{Materials and Methods}

\subsection{Raw material preparation}

Mangosteen, Garcinia mangostana Linn. was purchased from a mangosteen orchard (Rayong province, Thailand) and was harvested at 13th week after full blooming. The fruits of the weight between 55-65 g were incubated at $30 \pm 2{ }^{\circ} \mathrm{C}$ for 8 days to be fully ripe. Then, the peels were removed from the fruits. Prior to enzyme hydrolysis, the mangosteen aril browning was controlled by steam blanching until it reached $85^{\circ} \mathrm{C}$ at the center and holding for 3 min, then it was blended for 3 min until a homogenized fruit aril was obtained.

\subsection{Enzymatic hydrolysis}

The homogenized and anti-browning controlled mangosteen aril (200 g) was hydrolysed by Pectinex ${ }^{\circledR}$ Ultra SP-L (Novozymes Switzerland AG, Dittengen, Switzerland) which had enzymatic activity of 10,292 PGU/ml and produced from Aspergillus aculeatus and controlled the reaction temperature at $30 \pm 2^{\circ} \mathrm{C}$. The enzyme concentrations were varied into 7 levels $(0,0.5,1.0,1.5,2.0,2.5$, and $3.0 \% \mathrm{v} / \mathrm{w})$ and hydrolysis times were varied into 9 levels $(0,0.5,1.0,1.5,2,3,4,5$, and $6 \mathrm{~h})$. The hydrolysis reaction was stopped by heating at $100 \pm 5^{\circ} \mathrm{C}$ for 5 min. Then, hydrolysis efficiency was determined by the amount of reducing sugar as glucose using the method of Nelson-Somogyi (Nelson, 1944). All chemicals and solvents used in this study were analytical grade, purchased from Sigma Chemical Co., Ltd (St. Louis, MO. USA) and Sigma Aldrich Co., Ltd (Steinheim, Germany). All analyses were performed in triplicate.

\subsection{Determination of antioxidant activities}

\subsubsection{Sample preparation}

Preparation of sample was modified from the method of Velioglu et al. (1998). Mangosteen hydrolysate was extracted with $95 \%$ ethanol, kept in the dark at $25^{\circ} \mathrm{C}$ for $4.5 \mathrm{~h}$ and stored at $-20^{\circ} \mathrm{C}$ until further analysis.

\subsubsection{Antioxidant activities}

The antioxidant activities of sample extract were evaluated from DPPH and FRAP assays. The 2,2-diphenyl-1-picrylhydrazyl (DPPH) free radical scavenging activity was followed by the method of Maisuthisakul et al. (2007). A series of extract concentrations with different ratios of extract to methanol were prepared. Then $4.9 \mathrm{ml}$ of each dilution was mixed with $100 \mu \mathrm{l}$ of $5 \mathrm{mM}$ DPPH in methanol and were placed in the dark for $30 \mathrm{~min}$. The absorbance of three samples, the diluted sample with the addition of DPPH solution $\left(\mathrm{A}_{1}\right)$, the diluted sample without the addition of DPPH solution $\left(\mathrm{A}_{\mathrm{s}}\right)$, and DPPH solution $\left(\mathrm{A}_{0}\right)$ were read at $517 \mathrm{~nm}$ 
using a spectrophotometer with methanol as a blank. The decreased content of DPPH radical scavenging activity in each concentration of sample extract could be calculated by the formula as shown:

DPPH radical scavenging activity $(\%)=\left[\mathrm{A}_{0^{-}}\left(\mathrm{A}_{1}-\mathrm{A}_{\mathrm{S}}\right)\right] / \mathrm{A}_{0} \times 100$

The percentage of DPPH radical-scavenging activity was plotted against the sample extract concentration $(\mu \mathrm{g} / \mathrm{ml})$ to determine the amount of extract necessary to decrease $\mathrm{DPPH}$ radical concentration by $50 \%$ (called $\mathrm{EC}_{50}$ ). The unit of $\mathrm{EC}_{50}$ was later converted to $\mu \mathrm{g} / \mu \mathrm{g} \mathrm{DPPH}$ as follow:

$\mathrm{EC}_{50}(\mu \mathrm{g} / \mu \mathrm{g} \mathrm{DPPH})=[(\mu \mathrm{g}$ extract $/ \mathrm{ml}) /(\mu \mathrm{g} \mathrm{DPPH} / \mathrm{ml})]$

Ferric reducing antioxidant power (FRAP) assay was modified from the method of Benzie and Strain (1996). The sample extracts $(50 \mu \mathrm{l})$ were allowed to react with $950 \mu \mathrm{l}$ of FRAP solution (FRAP solution consist of $25 \mathrm{ml}$ of acetate buffer, $2.5 \mathrm{ml}$ of Ferric chloride solution and $2.5 \mathrm{ml}$ of TPTZ solution) and were placed in the dark for 4 min. The standard curve was linear between 100 and $700 \mu \mathrm{M}$ trolox. Results were expressed in $\mu \mathrm{M}$ trolox equivalent (TE)/g dw).

\subsection{Determination of total phenolic content}

Sample was likewise prepared as the determination of antioxidant activity. Total phenolic content was evaluated by the method of Waterhouse (2005). The standard curve was linear between 50-500 mg gallic acid/l. The results were expressed as mg gallic equivalent (GAE)/ $\mathrm{g}$ dw.

\subsection{Determination of total flavonoid}

Sample was likewise prepared as the determination of antioxidant activity. Total flavonoid content was evaluated by the method of Zhishen et al. (1999). The standard curve was linear between 20-100 mg catechin/l. The results were expressed as $\mathrm{mg}$ catechin equivalent (CE)/g dw.

\subsection{Determination of dietary fiber}

Total, soluble and insoluble dietary fibers were analyzed according to AOAC method (AOAC1995).

\subsection{Determination of prebiotic activity}

Prebiotic activity assay was modified from Huebner et al. (2007). Lactobacillus acidophilus La5, Bifidobacterium lactis Bb12 (Christian Hansen, Denmark) and Escherichia coli ATCC 25922 (Culture Collection Unit, Chulalongkorn hospital, Thailand) were used in this study. L. acidophilus La5 and B. lactis Bb12 were prepared by streaking onto MRS agar and MRS agar supplement with $0.05 \%$ L-cystein $\mathrm{HCl}$ (decrease of oxidation-reduction potential), respectively and streaking onto Tryptic soy agar (TSA) for E. coli ATCC 25922. Then, incubated at $37^{\circ} \mathrm{C}$ for $24-48 \mathrm{~h}$ under aerobic condition for L. acidophilus La5 and E. coli ATCC 25922, anaerobic condition in anaerobic jar with anaerogen gas pack (Mitsubishi) for B. lactis Bb12. After that, one colony from each plate was transferred into $10 \mathrm{ml}$ of MRS broth for L. acidophilus La5, MRS broth supplement with $0.05 \% \mathrm{~L}$-cystein $\mathrm{HCl}$ for B. lactis Bb12, and Tryptic soy broth (TSB) for E. coli ATCC 25922 and incubated overnight. For L. acidophilus La5, an additional transfer of $1 \%(\mathrm{v} / \mathrm{v})$ was transferred to MRS broth with $1 \% \mathrm{w} / \mathrm{v}$ glucose or $1 \% \mathrm{w} / \mathrm{v}$ samples. For B. lactis Bb12, an additional transfer of $1 \%(\mathrm{v} / \mathrm{v})$ was transferred to MRS broth supplement with $0.05 \% \mathrm{~L}-$ cystein $\mathrm{HCl}$ and $1 \% \mathrm{w} / \mathrm{v}$ glucose or $1 \% \mathrm{w} / \mathrm{v}$ samples. For $E$. coli ATCC 25922 , an additional transfer of $1 \%(\mathrm{v} / \mathrm{v})$ was transferred to minimal medium broth with $1 \% \mathrm{w} / \mathrm{v}$ glucose or $1 \% \mathrm{w} / \mathrm{v}$ samples and incubated overnight.

The prebiotic activity score was determined using the following equation:

Prebiotic activity score $=$

$$
\left[\frac{\left(\text { probiotic } \log \frac{\mathrm{cfu}}{\mathrm{ml}} \text { on the prebiotic at } 24 \mathrm{hr}-\text { probiotic } \log \frac{\mathrm{cfu}}{\mathrm{ml}} \text { on the prebiotic at } 0 \mathrm{hr}\right. \text { ) }}{\text { (probiotic } \log \frac{\mathrm{cfu}}{\mathrm{ml}} \text { on glucose at } 24 \mathrm{hr}-\text { probiotic } \log \frac{\mathrm{cfu}}{\mathrm{ml}} \text { on glucose at } 0 \mathrm{hr} \text { ) }}\right]-
$$

$$
\left[\frac{\left(\text { enteric } \log \frac{\mathrm{cfu}}{\mathrm{ml}} \text { on the prebiotic at } 24 \mathrm{hr}-\text { enteric } \log \frac{\mathrm{cfu}}{\mathrm{ml}} \text { on the prebiotic at } 0 \mathrm{hr}\right)}{\text { (enteric } \log \frac{\mathrm{cfu}}{\mathrm{ml}} \text { on glucose at } 24 \mathrm{hr}-\text { enteric } \log \frac{\mathrm{cfu}}{\mathrm{ml}} \text { on glucose at } 0 \mathrm{hr} \text { ) }}\right]
$$




\subsection{Statistical analysis}

Results of experiment were presented as mean \pm standard deviation of three independent determinations. All statistical analyses were performed with SPSS version 11.5. One- way analysis of variance (ANOVA) by Duncan's new multiple range test was used to compare the mean values. Differences were considered to be significant at $\mathrm{p}<0.05$.

\section{Results and Discussion}

\subsection{Effect of enzyme treatment on reducing sugars}

It was found that the more increasing the hydrolysis time and the enzyme concentration, the significantly higher the level of reducing sugar ( $\leq \leq 0.05$ ), as shown in Figure 1. It could be explained that pectinase can hydrolyze polysaccharide by cleaving the $\alpha-1,4$-glycosidic bond of galacturonic acid, so the reducing group was produced in depolymerized mangosteen aril (Wuttisit and Anprung, 2011; Chareonsiddhi and Anprung, 2010). However, the obtained reducing sugar was not significantly different $(\mathrm{p}>0.05)$ between using the enzyme concentration of $3.0 \%$ and $2.5 \%(\mathrm{v} / \mathrm{w})$. Using $2.5 \%(\mathrm{v} / \mathrm{w})$ of enzyme concentration can be resulted in all range of low to high reducing sugar levels of approximately 5 levels $(18,25,31,40$ and $45 \mathrm{mg}$ glucose/g fw) and hydrolyzed for 0,1 , 2, 4 and $6 \mathrm{~h}$. These conditions were selected for the study of bioactive compounds, soluble dietary fiber and prebiotic activity score of enzymatically depolymerized mangosteen aril.

\subsection{Antioxidant activity}

It can be seen from Table 1 that the antioxidant activity value of depolymerized mangosteen was significantly increased $(\mathrm{p} \leq 0.05)$ due to the increasing of hydrolysis time. At hydrolysis time over $4 \mathrm{~h}$, it had a minimum of $\mathrm{DPPH}$ value in form of $\mathrm{EC}_{50}$. The antioxidant activity was highest when $\mathrm{EC}_{50}$ value was lowest. On the other hand, FRAP value or the antioxidant activity was highest. Basically, these results indicate that the enzyme can hydrolyze and degrade plant cell wall components. So the intracellular contents, especially antioxidant substances, were easily released (Chen et al., 2011; Choudhari and Ananthanarayan, 2007). The bael fruit pulp treated with enzyme concentration of $2.5 \%(\mathrm{v} / \mathrm{w})$ and hydrolyzed at $6 \mathrm{~h}$ gave the highest antioxidant activities up to $18.85 \mu \mathrm{g} / \mu \mathrm{g}$ DPPH (Chareonsiddhi and Anprung, 2010). Antioxidant activities in the flesh and placenta of cantaloupe hydrolysate detected by DPPH method were 1.57, $0.66 \mu \mathrm{g} / \mu \mathrm{g}$ DPPH, respectively higher than the undegraded samples.(Wuttisit and Anprung, 2011). Increasing degree of hydrolysis for pectin in mango pulp had effect on antioxidant activity. The depolymerized mango pulp with reducing sugar content of $95 \mathrm{mg}$ glucose $/ \mathrm{g}$ $\mathrm{fw}$ (DP 95) has antioxidant activity in form of FRAP value as $28.2 \mu \mathrm{M} \mathrm{TE} / \mathrm{g} \mathrm{dw}$ (Kewalee and Anprung, 2010). It has a report that enzymatic extraction can give higher yield of antioxidant activity than the solvent extraction (Wang et al., 2011).

\subsection{Total phenolic and total flavonoid content}

The hydrolysis time at $6 \mathrm{~h}$ had given the highest total phenolic and flavonoid contents of $16 \mathrm{mg} \mathrm{GAE} / \mathrm{g}$ dw and $3.08 \mathrm{mg} \mathrm{CE} / \mathrm{g} \mathrm{dw}$, respectively as shown in Table 1 . The experiment was related with the different literature; for example, total phenolic and flavonoid contents were increased after enzymatic hydrolysis in black current juice (Landbo and Meyer, 2004), olive oil (Najafian et al., 2009), ginkgo leaves (Chen et al., 2011), and cactus pear (Ayoub et al., 2011). Total phenolic contents in the flesh and placenta of cantaloupe hydrolysate were 14.95, $39.72 \mathrm{mg} \mathrm{GAE} / 100 \mathrm{~g}$, respectively higher than the undegraded samples. And total flavonoid contents in the flesh and placenta of cantaloupe hydrolysate were $2.25,12.24 \mathrm{mg} \mathrm{CE} / 100 \mathrm{~g}$, respectively higher than the undegraded samples. (Wuttisit and Anprung, 2011). Total phenolic content in flesh and peel of red dragon fruit hydrolysate were $1,049.18,561.76 \mathrm{mg} \mathrm{GAE} / 100 \mathrm{~g}$, respectively higher than the undegraded samples, and total flavonoid content in the flesh and peel of red dragon fruit hydrolysate were $1,310.10,220.28 \mathrm{mg} \mathrm{CE} / 100 \mathrm{~g}$, respectively higher than the undegraded samples. (Sornyotha and Anprung, 2011) It can be explained that pectinase does not only degrade plant cell wall, but also improves releasing of intracellular contents as bioactive compounds such as phenolic and flavonoid. Moreover, it was found that enzymatic extraction improved phenol released from apple skin more than solvent extraction (Pinelo et al., 2008).

\subsection{Dietary fiber}

From the Table 2, total dietary fiber content in sample without hydrolysis (A1) was found not different from sample with hydrolysis (A2) ( $>0.05)$. On the other hand, the soluble dietary fiber of A2 was higher than A1 $(16.56,12.91 \mathrm{~g} / 100 \mathrm{~g} \mathrm{dw})$, respectively. These results were caused by Pectinex Ultra SP-L which is complex enzyme that can be divided into 3 groups: depolymerase, pectinesterase and protopectinase. Depolymerase can cleave the $\alpha-1,4$-glycosidic bonds of pectic substances, pectinesterase can catalytically deesterify the methyl ester linkages of pectic substances to release acidic pectins and methanol. In addition, protopectinase can 
hydrolyze insoluble protopectin to get more highly soluble pectin, therefore these enzymes are able to produce soluble dietary fiber. It was related with the experiments in fully ripe fresh Thai bael fruit degraded by enzyme that the soluble dietary fiber of bael fruit hydrolysate $(4.58 \mathrm{~g} / 100 \mathrm{gfw})$ was higher than nonenzyme treated sample (3.51g/100gfw) (Chareonsiddhi and Anprung, 2010). And the soluble dietary fiber in flesh and peel of cantaloupe hydrolysate $(0.76,0.52 \mathrm{~g} / 100 \mathrm{gfw}$, respectively) were higher than undegraded enzyme $(0.65,0.32$ $\mathrm{g} / 100 \mathrm{gfw}$, respectively) (Wuttisit and Anprung, 2011).

\subsection{Prebiotic activity score}

Lactobacilli and Bifidobacterium strains were chosen to test the prebiotic activity score because they are used in dairy foods and have good potential probiotic properties. From the determination of prebiotic activity of A1 (sample without hydrolysis) compared with A2 (sample with hydrolysis) and inulin, the amount of bacterial cell grown in media with mangosteen aril samples (A1 and A2), inulin and glucose for $24 \mathrm{~h}$ can be found (shown in Table 3). The amount of L. acidophilus La5 and B. lactis Bb12 grown on media with inulin and media with A2 were significantly higher $(p \leq 0.05)$ than ones grown on media with A1 and media with glucose. On the other hand, the amount of E.coli ATCC 25922 (representative of Enteric bacteria) grown on glucose (no prebiotic) was significantly higher $(\mathrm{p} \leq 0.05)$ than other media with prebiotic. Moreover, prebiotic activity scores were derived from cell density values as shown in Figure 2. It was found that the highest prebiotic activity scores wer L. acidophilus La5 and B. lactis Bb12 grown on media with inulin (0.41, 0.38, respectively), followed by L. acidophilus La5 and B. lactis Bb12 grown on media with A2 (0.21, 0.17, respectively), and the lowest scores were L. acidophilus La5 and B. lactis Bb12 grown on media with A1 $(0.16,0.12$, respectively). From these results, it can be concluded that the different bacterial strain affected to the different prebiotic activity score owing to the differences in the metabolic capacity of related strains apparently existed, and utilization of prebiotics by these related bacteria requires the presence of specific hydrolysis and transport systems for the particular prebiotic (Hubner et al., 2007). Moreover, prebiotic activity score of B. lactis Bb12 was lower than L.acidophilus La5, this may be caused that the different cell density value between prebiotics, and glucose of $\mathrm{B}$. lactis Bb12 was less than L.acidophilus La5 affected to the prebiotic activity score of B. lactis Bb12 lower than L.acidophilus La5. When compared the prebiotic activity score which used depolymerized mangosteen aril as prebiotic with other studies which used bael fruit hydrolyzate as prebiotic, it was found that probiotic bacteria were higher grown on depolymerized mangosteen aril than bael fruit hydrolyzate. This may be caused that the depolymerized mangosteen aril was hydrolyzed to smaller molecules than bael fruit hydrolyzate (Charoensiddhi and Anprung, 2010) that appropriated for supporting the growth of probiotics.

\section{Conclusion}

The Pectine ${ }^{\circledR}$ Ultra SP-L had a potential to release the bioactive compounds from plant cell wall and affected to changes in prebiotic activity and amount of bioactive compounds from enzymatically depolymerized mangosteen. Results show the significant increasing in amount of antioxidant activity, total phenolic, total flavonoid, soluble dietary fiber as well as promoting the growth of probiotics. It could be said that enzymatically depolymerized mangosteen was effective to be used as sources of antioxidant, dietary fiber, and prebiotic. Moreover, the depolymerized mangosteen aril as prebiotic give the highest activity scores among the studied Thailand-grown fruits. Regarding to a slimy characteristic of mangosteen hydrolysate and the results of bioactive compound from this study, it could be possible to further study about rheological profile of enzymatically depolymerized mangosteen aril for using as a valuably functional stabilizer in the emulsion system.

\section{Acknowledgments}

Authors are thankful for the funding by the Integration Project: Innovation for the Improvement of Food Safety and Food Quality for New World Economy, Government Research Budget, and Graduate School Chulalongkorn University, Thailand.

\section{References}

AOAC. (1995). Official Methods of Analysis of AOAC International. Association of Official Analytical Chemists, Washington, D. C.

Ayoub, T. E. M., Samahy, S. K. E., Kroh, L. W., \& Rohn, S. (2011). Identification and quantification of flavonol aglycons in cactus pear (Opuntia ficus indica) fruit using a commercial pectinase and cellulase preparation. Food Chemistry, 124, 1177-1184. http://dx.doi.org/10.1016/j.foodchem.2010.07.032

Benzie, I. F. F., \& Strain, J. J. (1996). The ferric reducing ability of plasma (FRAP) as a measure of "Antioxidant Power" the FRAP assay. Analytical Biochemistry, 239, 70-76. http://dx. doi.org/10.1006/abio.1996.0292 
Chandini, S. K., Rao, L. J., Gowthaman, M., K., Haware, D. J., \& Subramanian., R. (2011). Enzymatic treatment to improve the quality of black tea extracts. Food Chemistry, 127, 1039-1045. http://dx.doi.org/10.1016/j.foodchem.2011.01.078

Charoensiddhi, S., \& Anprung, P. (2010). Characterization of bael fruit (Aegle marmeols[L.] correa) hydrolysate as affected by enzyme treatment. Food Biochemistry, 34, 1249-1267. http://dx.doi.org/ 10.1111/j.1745-4514.2009.00333.x

Chen, S., Xing, X. H., Huang, J. J., \& Xu, M. S. (2011). Enzyme-assisted extraction of flavonoids from Ginkgo biloba leaves: Improvement effect of flavonol transglycosylation catalyzed by Penicillium decumbens cellulose. Enzyme and Microbial Technology, 48, 100-105. http://dx.doi.org/10.1016/j.enzmictec.2010.09.017

Choudhari, S. M. \& Ananthanarayan, L. (2007). Enzyme aided extraction of lycopene from tomato tissues. Food Chemistry, 102, 77-81. http://dx.doi.org/10.1016/j.foodchem.2006.04.031

Cinar. (2005.a). Stability studies on the enzyme extracted sweet potato carotenoproteins. Food Chemistry, 89, 397-401. http://dx.doi.org/10.1016/j.foodchem.2004.02.048

Cinar. (2005.b). Effect of cellulose and pectinase concentrations on the colour yield of enzyme extracted plant carotenoids. Process Biochemistry, 40, 945-949. http://dx.doi.org/10.1016/j.procbio.2004.02.022

Ducasse, M. A., Llauberes, R. M., Lumley, M., \& Williams, P. (2010). Effect of macerating enzyme treatment on the polyphenol and polysaccharide composition of red wines. Food Chemistry, 118, 369-376. http://dx.doi.org/10.1016/j.foodchem.2009.04.130

Fu, Y. J., Liu, W., Zu, Y. G., Tong, M. H., \& Li, S. M. (2008). Enzyme assisted extraction of lutein and apigenin from pigeonpea [Cajanus cajan (L.) Millsp.] leaves. Food Chemistry, 111, 508-512. http://dx.doi.org/10.1016/j.foodchem.2008.04.003

Ghaazi, I., Arrojo, L. F., Arellano, H. G., Ferrer, M., Ballesteros, A., \& Plou, F. A. (2007). Purification and kinetic characterization of a fructosyltransferase from Aspergillus aculeatus. Journal of Biotechnology, 128, 1, 204-211. doi.org/10.1016/j.jbiotec.2006.09.017

Huebner, J., Wehling, R. L., \& Hutkins, R. W. (2007). Functional activity of commercial prebiotics. International Dairy Journal, 17, 770-775. http://dx.doi.org/10.1016/j.idairyj.2006.10.006

Kewalee, K. \& Anprung, P. (2010). Effect of depolymerized mango pulp as a stabilizer in, oil-in-water emulsion containing sodium caseinate. Food and Bioproducts Processing, 88, 202-208. http://dx.doi.org/10.1016/j.fbp.2010.01.004

Landbo, A. K., \& Meyer, A. S. (2004). Effects of different enzymatic maceration treatments on enhancement of anthocyanins and other phenolics in black currant juice. Innovative Food Science and Emerging Technologies, 5, 503-513. http://dx.doi.org/10.1016/j.ifset.2004.08.003

Maisuthisakul, P., Suttajit, M., \& Pongsawatmanit, R. (2007). Assessment of phenolic content and free radical scavenging capacity of some Thai indigenous plants. Food Chemistry, 100, 1409-1418. http://dx.doi.org/10.1016/j.foodchem.2005.11.032

Morton, J. (1987). Fruits of Warm Climate. Miami, FL. USA.

Najafian, L., Ghodsvali, A., Khodaparast, M. H., \& Diosady, L. L. (2009). Agueous extraction of virgin olive oil using industrial enzymes. Food Research International, 42, 171-175. http://dx.doi.org/10.1016/j.foodres.2008.10.002

Nelson, N. (1944). A photometric adaptation of the Somogyi method for determination of glucose. Applied Microbiology, 93, 505-511.

Osman, M. B. \& Milan, A. R. (2006). Mangosteen. Garcinia mangostana L. International Central Underutilised Crops, Southampton, UK.

Oszmiański J., Wojdyło A., \& Kolniak, J. (2011). Effect of pectinase treatment on extraction of antioxidant phenols from pomace, for the production of puree-enriched cloudy apple juices. Food Chemistry, 127, 623-631. http://dx.doi.org/10.1016/j.foodchem.2011.01.056

Palapol, Y., Ketsa, S., Stevenson, D., Cooney, J. M., Allan, A. C., \& Ferguson, I.B. (2009). Colour development and quality of mangosteen (Garcinia mangostana L.) fruit during ripening and after harvest. Postharvest Biology and Technology, 51, 349-353. http://dx.doi.org/10.1016/j.postharvbio.2008.08.003

Percival, M. (1996). Antioxidant. Clinical Nutrition Insights. Advanced Nutrition Publications, Inc. 
Pinelo, M., \& Meyer, S. (2008). Enzyme-assisted extraction of antioxidants: release of phenols from vegetal matrixes. Electronic Journal of Environmental, Agricultural and Food Chemistry, 8, 3217-3220.

Pinelo, M., Zornoza, B., \& Meyer, A. S. (2008). Selective release of phenols from apple skin: Mass transfer kinetics during solvent and enzyme-assisted extraction. Separation and Purification Technology, 63, 620-627. http://dx.doi.org/10.1016/j.seppur.2008.07.007

Sornyotha, K., \& Anprung, P. (2011). Influence of enzyme treatment on bioactive compounds and colour stability of betacyanin in flesh and peel of red dragon fruit Hylocereus polyrhizus (Weber) Britton and Rose. International Food Research Journal 18, 4, 1437-1448

Velioglu, Y. S., Massa, G., Gao, L., \& Oomah, B. D. (1998). Antioxidant activity and total phenolics in selected fruits, vegetables and grain products. Agricultural Food Chemistry, 46, 4113-4117. http://dx.doi.org/10.1021/jf9801973

Wang, Y., Zu, Y., Long, J., Fu, Y., Li, S., \& Zhang, D. (2011). Enzymatic water extraction of taxifolin from wood sawdust of Larix gmelini (Rupr.) Rupr. and evaluation of its antioxidant activity. Food Chemistry, 126, 1178-1185. http://dx.doi.org/10.1016/j.foodchem.2010.11.155

Waterhouse, A. L. (2005). Determination of total phenolics. In Wrolstad R.E., Acree, T. E., Decker, E. A., Penner, M. H., Reid, D. S., Schwarts, S. J., Shoemaker, C. F., Smith, D., \& Sporns, P. (eds.), Handbook of Food Analytical Chemistry:Pigments, Colorants, Flavors, Texture, and Bioactive Food Components, 463-481. New Jersey: John Wiley and Sons.

Wuttisit, N., \& Anprung, P. (2011). Effect of pectinase on volatile and functional bioactive compounds in the flesh and placenta of Sunlady cantaloupe. International Food Research Journal, 18, 792-800.

Yu, L., Zhao, M., Yang, B., Zhao, Q., \& Jiang, Y. (2007). Phenolics from hull of Garcinia mangostana fruit and their antioxidant activities. Food Chemistry, 104, 176-181. http://dx.doi.org/10.1016/j.foodchem.2006.11.018

Zadernowski, R.,Czaplicki, S., \& Naczk, M. (2009). Phenolic acid profiles of mangosteen fruits (Garcinia mangostana). Food Chemistry, 112, 685-689. http://dx.doi.org/10.1016/j.foodchem.2008.06.030

Zhishen, J., Mengcheng, T., \& Jianming, W. (1999). The determination of flavonoid contents in mulberry and their scavenging effects on superoxide radicals. Food Chemistry, 64, 555-559. http://dx.doi.org/10.1016/S0308-8146(98)00102-2

Table 1. Effect of enzyme hydrolysis on bioactive compounds of depolymerized mangosteen aril

\begin{tabular}{|c|c|c|c|c|c|}
\hline Bioactive compounds & \multicolumn{5}{|c|}{ Hydrolysis time (h) } \\
\hline & 0 & 1 & 2 & 4 & 6 \\
\hline \multicolumn{6}{|l|}{ Antioxidant activities } \\
\hline $\begin{array}{c}\text { DPPH } \\
\left(\mathrm{EC}_{50}, \mu \mathrm{g} \mathrm{dw}^{1} / \mu \mathrm{gDPPH}\right)\end{array}$ & $11.53 \pm 0.13^{\mathrm{a}}$ & $6.37 \pm 0.06^{\mathrm{b}}$ & $5.70 \pm 0.11^{\mathrm{b}, \mathrm{c}}$ & $4.17 \pm 0.09^{\mathrm{c}, \mathrm{d}}$ & $3.05 \pm 0.04^{\mathrm{d}}$ \\
\hline $\begin{array}{r}\text { FRAP } \\
\left(\mu \mathrm{M} \mathrm{TE}^{2} / \mathrm{g} \mathrm{dw}\right)\end{array}$ & $34.4 \pm 0.53^{\mathrm{d}}$ & $35.67 \pm 0.81^{\mathrm{d}}$ & $37.53 \pm 0.50^{\mathrm{c}}$ & $42.60 \pm 1.24^{\mathrm{b}}$ & $45.53 \pm 0.70^{\mathrm{a}}$ \\
\hline $\begin{array}{l}\text { Total phenolic } \\
\left(\mathrm{mg} \mathrm{GAE}^{3} / \mathrm{g} \mathrm{dw}\right)\end{array}$ & $9.03 \pm 0.50^{\mathrm{e}}$ & $10.57 \pm 0.31^{\mathrm{d}}$ & $12.53 \pm 0.35^{\mathrm{c}}$ & $14.57 \pm 0.70^{\mathrm{b}}$ & $16.00 \pm 0.82^{\mathrm{a}}$ \\
\hline $\begin{array}{l}\text { Total flavonoid } \\
\left(\mathrm{mg} \mathrm{CE}^{4} / \mathrm{g} \mathrm{dw}\right)\end{array}$ & $1.17 \pm 0.08^{\mathrm{d}}$ & $1.68 \pm 0.14^{\mathrm{c}}$ & $2.35 \pm 0.32^{\mathrm{b}}$ & $2.66 \pm 0.17^{\mathrm{b}}$ & $3.08 \pm 0.15^{\mathrm{a}}$ \\
\hline
\end{tabular}

Each value represented a mean \pm standard deviation.

Means with the different letter in the row are significantly difference at $p \leq 0.05$.

${ }^{1} \mathrm{dw}=$ dry weight, ${ }^{2} \mathrm{TE}=$ Trolox equivalents, ${ }^{3} \mathrm{GAE}=$ gallic acid equivalents,${ }^{4} \mathrm{CE}=$ catechin equivalents. 
Table 2. Effect of enzyme hydrolysis on total dietary fiber (TDF), soluble dietary fiber (SDF) and insoluble dietary fiber (IDF) of depolymerized mangosteen aril

\begin{tabular}{|l|c|c|}
\hline \multicolumn{1}{|c|}{ Total dietary fiber } & $\mathrm{A}^{2}$ & $\mathrm{~A}^{3}$ \\
\hline \multicolumn{1}{|c|}{$\left(\mathrm{g} / 100 \mathrm{~g} \mathrm{dw}^{\mathrm{1}}\right)$} & & $25.60 \pm 0.21^{\mathrm{ns}}$ \\
\hline Total dietary fiber & $25.15 \pm 0.50^{\mathrm{ns}}$ & $16.56 \pm 0.10^{\mathrm{a}}$ \\
\hline Soluble dietary fiber & $12.91 \pm 0.13^{\mathrm{b}}$ & $9.04 \pm 0.11^{\mathrm{b}}$ \\
\hline Insoluble dietary fiber & $12.24 \pm 0.37^{\mathrm{a}}$ & \\
\hline
\end{tabular}

Each value represented a mean \pm standard deviation.

Means with the different letter in the row are significantly difference at $\mathrm{p} \leq 0.05$.

${ }^{1} \mathrm{dw}=$ dry weight basis, ${ }^{2} \mathrm{~A} 1=$ Sample with no hydrolysis, ${ }^{3} \mathrm{~A} 2=$ Sample with hydrolysis .

Table 3. Effect of enzyme hydrolysis on the increasing of bacterial cell density between 0 and $24 \mathrm{~h}$ in different carbohydrates

\begin{tabular}{|l|c|c|c|c|}
\hline \multicolumn{1}{|c|}{ Bacterial culture } & \multicolumn{4}{|c|}{ Cell density $\left[\log _{10}(\mathrm{cfu} / \mathrm{ml})\right]$} \\
\hline & Glucose & Inulin & $\mathrm{A} 1^{1}$ & $\mathrm{~A} 2^{2}$ \\
\hline L. acidophilus $\mathrm{La} 5$ & $2.02 \pm 0.04^{\mathrm{c}}$ & $2.38 \pm 0.04^{\mathrm{a}}$ & $2.22 \pm 0.03^{\mathrm{b}}$ & $2.35 \pm 0.12^{\mathrm{a}}$ \\
\hline B. lactis Bb12 & $2.14 \pm 0.06^{\mathrm{b}}$ & $2.45 \pm 0.09^{\mathrm{a}}$ & $2.27 \pm 0.03^{\mathrm{b}}$ & $2.42 \pm 0.09^{\mathrm{a}}$ \\
\hline E. coli ATCC 25922 & $2.11 \pm 0.02^{\mathrm{a}}$ & $1.62 \pm 0.02^{\mathrm{c}}$ & $1.98 \pm 0.03^{\mathrm{b}}$ & $2.02 \pm 0.06^{\mathrm{b}}$ \\
\hline
\end{tabular}

Each value represented a mean \pm standard deviation.

Means with the different letter in the row are significantly difference at $p \leq 0.05$.

${ }^{1} \mathrm{~A} 1=$ Sample with no hydrolysis, ${ }^{2} \mathrm{~A} 2=$ Sample with hydrolysis.

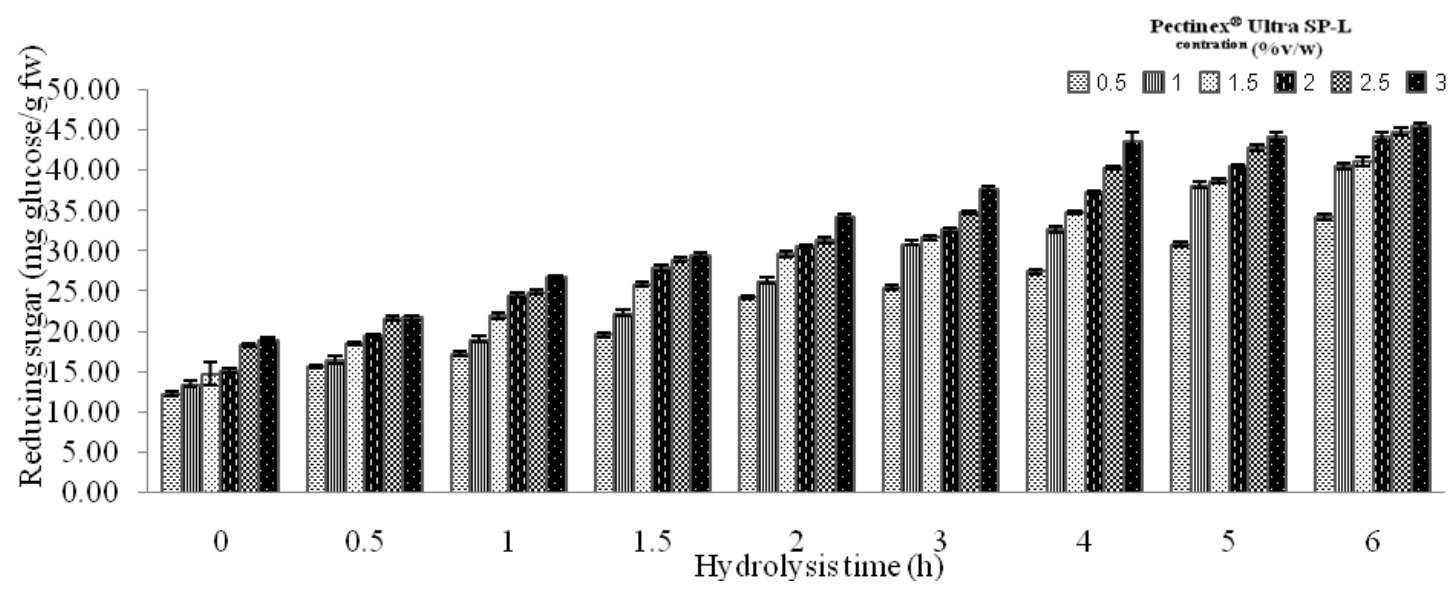

Figure 1. Changes in the reducing sugar content during enzyme hydrolysis 


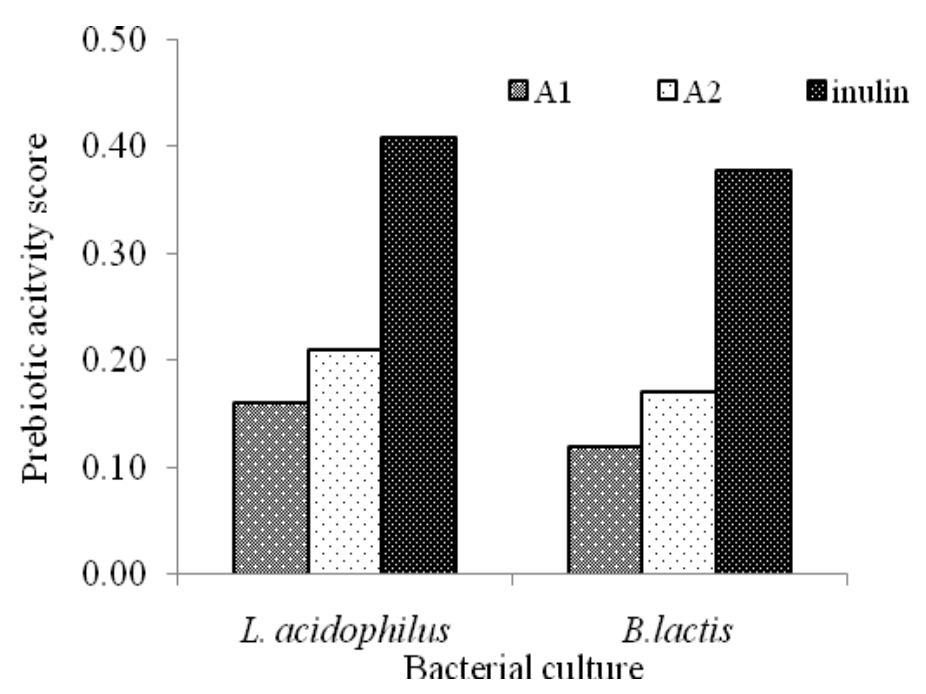

Figure 2. Prebiotic activity score of depolymerized mangosteen aril A1 = Sample with no hydrolysis, A2 = Sample with hydrolysis 